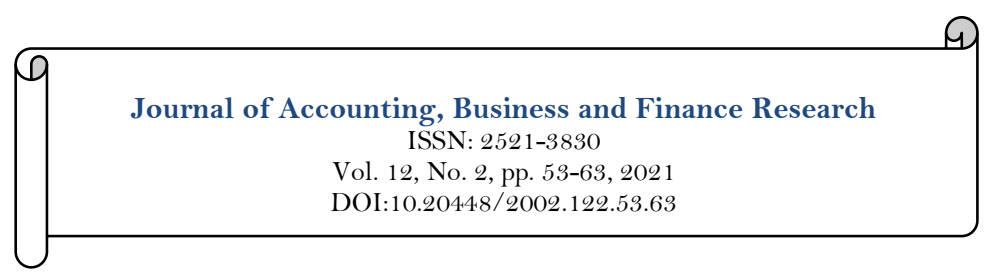

\title{
Electronic Funds Transfer and Service Delivery in SACCOs: A Case Study of Ng'arisha SACCO, Bungoma, Kenya
}

\author{
Jacinta Nalyanya ${ }^{1 *}$ \\ Joshua Olang'o Abuya ${ }^{2}$ \\ Arnety Nangila Makokha ${ }^{3}$
}

${ }^{\prime}$ Student School of Business and Economics, Kibabii University, Kenya.

Email:jacknalyanya@gmail.com

'Senior Lecturer, School of Business and Economics, Kibabii University, Kenya.

${ }^{s}$ Senior Lecturer, School of Business and Economics, Alupe University College, Kenya.

\begin{abstract}
Electronic funds transfer is generally expected to improve efficiency in funds transfers, payments, reporting, receipting and service delivery in any organization. However, the SACCO Societies Regulatory Authority (SASRA) reports of 2018 show that despite Savings and Credit Cooperatives (SACCOs) having institutionalized electronic operations in their accounting process, efficiency and effectiveness in service delivery remains elusive. The main objective is to determine the effect of electronic funds transfer on service delivery in Ng'arisha SACCO, Bungoma, Kenya. The research was guided by Schumpeter's theory of innovation and technology acceptance and used descriptive survey research design. The total target population used in the study comprises 121 respondents. Census sampling was used where the entire targeted population was sampled. Data was gathered using questionnaires with closed-ended structured questions that were prepared on a five-point Likert scale. Statistical Package for Social Sciences (SPSS) version 26 software was utilized for data analysis. Data was analyzed in the form of descriptive and inferential statistics. The research hypothesis Ho1 posits that the transfer of e-funds has no significant effect on service delivery in SACCOs. The model was significant and so the null hypothesis was rejected on the grounds that the transfer of e-funds had a significant and moderately strong positive linear correlation with service delivery in SACCOs. Based on the discoveries, service delivery is crucial in the SACCO industry. As a result, there is a strong link between e-funds transfer practices and Ng'arisha SACCO's service delivery. The study recommends that SACCOs should employ electronic means of transferring funds for their operations to enhance service delivery.
\end{abstract}

Funding: This study received no specific financial support.

Competing Interests: The authors declare that they have no competing interests.

\section{Introduction}

\subsection{Background Information of the Study}

Electronic accounting practices are expected to boost the efficiency in the transfer of funds, payments, reporting, invoicing, receipting and service delivery (SD) in any organization (Chau \& Lai, 2015). However, 
SASRA (2018) showed that despite Savings and Credit Cooperatives (SACCOs) having institutionalized electronic operations in their accounting processes, efficient and effective service delivery remains elusive in most of their aspects of reporting, payment and funds transfer. There has been a decline in the membership of SACCOs because of inadequate adjustments to satisfy the different credit needs of its members and slow product/service delivery due to long decision procedures (SASRA, 2018). This has prompted this research to investigate the effect of electronic accounting practices on SD in SACCOs, specifically, the Ng'arisha SACCO in Bungoma County, Kenya.

Chau and Lai (2015) describe e-accounting as a practice which employs the use of a computer-based accounting system that relies on technology to capture and process accounting information in organizations. In their study, the electronic accounting practices reviewed included e-reporting, e-receipting, cash transfer, ebilling, e-invoicing and e-auditing. Stefanou (2006) defines electronic accounting as the use of online automation in the accounting function of businesses, just as e-mail is a computerized means of sending conventional mail, electronic accounting is "electronic modification" of the conventional handbook and paperbased accounting procedures (Stefanou, 2006). Despite the fact that an accounting information system does not require the use of a computer to operate, he found that the word AIS is mainly used to refer to computer-based AIS. The terms "electronic accounting" and "reporting on financial statements" are used in this analysis to describe any accounting system that uses information and communication technology (ICT) to carry out its functions. The study measured e-accounting practices in terms of e-reporting, e-invoicing, e-payment, erecording and e-processes. The current study reviews e-accounting in terms of e-funds transfer, e-payments and e-reporting.

The research will endeavor to examine the effect of electronic accounting practices with consideration of e-funds transfer, e-payments and e-reporting on SD in Ng'arisha SACCO, Bungoma Kenya. According to Boeuyer (2016) the e-funds transfer practice converts cash into electronic money that can be sent from one individual to another via a media channel through a service provider. Sadona (2016) goes on to describe efunds transfer as an electronic money transfer practice made from one person to another person (p2p), i.e. a working relative sends money to help family members at home through e-banking (Sadona, 2016). In this study electronic transfer was measured using mobile banking and Western Union.

Maiyo (2015) defines an electronic payment system (EPS) as the payment of goods or services by virtual money rather than cash or check, through mail, or in person. Many people today pay electronically instead of paying in person. Secure internet transactions are provided by various virtual payment systems. Hla and Teru (2015) define e-payment systems as internet platforms used to pay service providers. They also state that EPSs are divided into four categories: credit and debit cards, electronic currency, micropayment systems, and session-level protocols for secure communications. Electronic currency and micropayment systems were used to measure EPSs in this study.

The electronic recording and reporting systems as defined by Jenkins (2018) are used by SACCOs to record, report, process, store and send data. One aspect of e-reporting is e-invoicing. Temple (2015) defines ereporting as generation and dissemination of reports using online platforms to provide stakeholders with enhanced access and accountability. An electronic invoice (e-invoice) can be easily integrated into a customer's accounts payable system since it is sent electronically via the internet rather than being paper-based. The electronic receipt, or e-receipt, is another aspect of e-reporting and is an electronic receipt for any product or service that was purchased. E-reports can also be in the form of electronic disclosure, which entails disclosing financial statements using electronic media (Jenkins, 2018). In this study, e-reporting was measured by einvoicing and e-disclosure reports.

Service distribution, according to the Municipal Research and Service (2015), is the process of producing a service. It is evaluated in terms of the organization's efficacy, utility, consumer satisfaction, and profitability. Whitaker (2014) agrees with this definition and points out that, based on the type of service provided, every service has a central role in transforming the user, and that the consumer gains the most. He evaluates SD in terms of real time service, total number of clients attended to, and customer satisfaction. In this study, it is measured by the number of loans disbursed and the number of customers served. Government regulations are the moderating variable in the relationship between electronic accounting practices and SD. Government regulations include the SASRA (2018) guidelines and cooperatives laws.

Tazik and Mohamed (2014) investigated the impact of accounting information system effectiveness and foreign ownership structure on audit report quality in SACCOs. The data was obtained through structured questionnaire surveys administrated to senior accountants from SACCOs in Malaysia, and secondary data was collected from the participants' 2011 financial reports. This study used a multiple regression analysis and audit reporting quality as a function of explanatory variables. The results indicate that the effectiveness of accounting information systems has been enhanced by the introduction of electronic accounting practices. Furthermore, accounting information systems and foreign ownership have a considerable negative association. Generally, the outcome of this study generates evidence to support the resource-based theory, which identifies accounting information systems as a resource that could improve the timeliness of corporate reporting. The current study adopted the multiple regression analysis method, which could result in different outcomes.

Henry, Adeniran, and Olwale (2014) examined the extent to which accounting information management has raised bank revenue in Nigeria. Accounting parameters for liquidity, credit rating, cash flow, wage rate, 
exchange rate, and rate of inflation were defined as pre-determined variables in the research model, whereas profitability was the determined variable. The work involves fitting a logical model into the collected time data using the ordinary least squares (OLS) regression technique, as well as other model validity methods including $\mathrm{R}^{2}$, multiple correlation coefficient ( $\mathrm{r}$ ), Durbin-Watson, Akaike Information Criterion (AIC), Schwarz Information Criterion (SIC), and F-statistic. The model was further evaluated for stationarity utilizing the unit root test as well as the augmented Dickey-Fuller method (ADF). An $\mathrm{R}^{2}$ value of $80.24 \%$, a correlation coefficient of 0.90 , a Durbin-Watson value of 1.76, an AIC value of 7.48, a SIC value of 7.87, and an F-statistic of 43.13, with a significance value of 0.000034 , demonstrate that accounting information has a considerable influence on the increase of profitability in the Nigerian banking industry. Furthermore, the model's stationarity test revealed that profitability and all of the explanatory variables studied in this research have a short-run connection. As a result, having adequate accounting knowledge has a positive impact on the profitability of the Nigerian banking industry, resulting in proactive policy options to effectively control credit quality, cash flow, and other explanatory variables to improve banking industry efficiency in the country. The OLS regression technique was used for the analysis, which is model-based and somewhat complex for elementary analysis, so the current study uses a simple regression analysis to analyze the findings.

Murungi and Kayigamba (2015) conducted a study on how computerized accounting systems have impacted financial reporting in microfinance institutions (MFIs) in Rwanda. The study analyzed the characteristics of computerized accounting and how they affect the quality of financial reports. Primary data was gathered via questionnaires. The study discovered that $98 \%$ of the MFIs agreed to the use of cash-based and accrual-based systems of accounting, 38\% admitted that accountability increased as a result of computerized accounting, while $31 \%$ of the participants held that the system provides accounting records in a timely manner. Due to the level of development of accounting packages, the study suggested timely and continual training for both accounting and finance employees. The research provides insight for the management in understanding the role of applying accounting packages to generate effective and efficient financial statements; however, it does not explain the importance of electronic funds transfer and electronic payments, which work alongside electronic reporting to enhance SD.

Muhindo and Zhou (2014) conducted a study on accounting information systems and the profitability level of small-scale businesses in Nairobi, Kenya. The study collected secondary data which was used to analyze the issue of repetitive unsatisfactory performance in small-scale businesses that do not use computerized accounting systems. According to the findings, there was a positive correlation between computerized accounting systems and small-scale firm revenue. The authors suggested that decision makers need to create tax cuts or tax relief on tools that can be applied within the accounting systems. The research adopted a secondary data approach even though electronic accounting practices and SD are abstract concepts that would be better measured using primary data tools to capture respondents' views. The current research collects primary data via questionnaires, which is likely to offer a different perspective.

A SACCO is an autonomous, separate, and independently-owned cooperative that belongs to and is governed by its members, who share the common bond of saving together and lending to one another at a fair interest rate. It is run and managed by people who share a common connection, such as working for the same company, attending the same church, organization, or social fraternity, or living/working in a similar environment (Olubendi, 2016). In Kenya, the SACCO sub-sector has grown at a rate of about $25 \%$ per year in recent years, and it now leads in savings mobilization with KSh 180 billion and an asset base of over KSh 200 billion. SACCO-organized savings account for $31 \%$ of all savings in the country. As a result, SACCOs have aided in the mobilization of economic energy and have played a vital role in achieving the national Vision 2030. This sub-sector plays a crucial role in Kenya's socio-economic growth (Njuguna, 2014). All SACCOs run back office accounting services and have been in a position to call up over KSh 180 billion, which amounts to almost $31 \%$ of the country's savings, and issue loans to the tune of KSh 120 billion. SACCOs have registered an enormous climb from the mid-1970s and have now attained an average climb rate of $25 \%$ a year in deposits and assets. SACCOs have also created job opportunities for citizens, thus contributing to the government's the goals of achieving Vision 2030. SACCOs have developed at a higher rate and now serve 3.7 million people. The SACCOs with front office service activities (FOSAs) have expanded into specific banking activities, which includes depositing, saving, debit card business (ATM) and the movement of money locally and internationally (Kinuthia, 2017).

Ng'arisha SACCO Society Ltd., which is the case study for the current research, was started in April 1978 (registration No. CS/NO 2876) to encourage teachers in Bungoma to save and mobilize their own resources and savings and also encourage internal lending for productive and provident purposes. Currently, the majority of SACCO members are employees of Ng'arisha SACCO, Teachers Service Commission, Kenya National Union of Teachers, and Public Service Commission. The SACCO operates fully under the ethics and ethos of cooperative principles and values, and by December 2004, it had an active membership of approximately 6000 and a registered membership of 11,350 who are spread within the district and its environment (Ng'arisha SACCO, 2018). During the same period, the SACCO had a share capital of over KSh 493 million and total outstanding loans of KSh 379 million. In an effort to take its services closer to members, the society has three satellite offices, namely the Naitiri office, the Kimilili office and the Sirisia office. The 
SACCO has embraced technology for several of its services, including cash transfers, some payments, and reporting. This study endeavors to determine if the technology has affected SD in any way and how.

\subsection{Statement of the Problem}

Electronic accounting practice is generally expected to improve the level of efficiency in funds transfer, payments, reporting, invoicing and receipting, and thus SD, in any organization (Chau \& Lai, 2015). However, SASRA (2018) showed that despite SACCOs having institutionalized electronic operations in their accounting process, efficacy in the number of loans disbursed and the number of customers served remains elusive among most aspects of reporting, payments and funds transfer. SACCO movements are facing major challenges in their operations due to the emergence of stiff competition from banks and mobile banking. There has been a decline in the membership of SACCOs because of inadequate adjustments to cater for members' different credit needs and inadequate speed of services because of lengthy decision procedures (SASRA, 2018). To adapt to market changes, a number of SACCOs, including Ng'arisha SACCO, have employed the use of electronic SD, especially in the areas of funds transfer, payments, and reporting. However, there is little that has been reported on as a result of this new dimension of technological adoption. A report by SASRA (2017) revealed that SACCOs are still struggling with the problem of poor record keeping, inconclusive reports and inefficient funds management, even with the adoption of technology in their operations. So far, $68 \%$ of SACCOs regulated by SASRA have fully adopted technology in their operations, yet only $34 \%$ of them were able to demonstrate effectiveness in reporting, recording and funds management, raising the question of whether eaccounting practices affect the SD of SACCOs, hence this study. Most of the studies in this field have focused on the shortcomings of the cooperative laws and their negative effects on operations and influence in the accrual of savings (Sharma, 2016). They have disregarded the effects of electronic accounting on SD, which has brought new processes to make the financial sector more desirable.

\subsection{Specific Objectives of the Study}

The primary aim is to examine the effect of e-funds transfer practices on service delivery in Ng'arisha SACCO, Bungoma, Kenya.

\subsection{Research Hypothesis \\ $\mathrm{H}_{0}$ 1: Electronic funds transfers have no statistically significant effect on service delivery in Ng'arisha SACCO, Bungoma, Kenya.}

\subsection{Significance of the Study}

The outcome of this study may be of importance as it provides information on the status of electronic accounting practices in Ng'arisha SACCO and, by extension, other accounting institutions, such as commercial banks, and provides ways of improving electronic accounting services in all accounting institutions. The outcome of the study will also have statistical significance for financial institutions in Kenya as it will provide insights for the improvement of electronic accounting in the country. The findings will also guide policy formulation by the government in the area of electronic accounting and SD. Furthermore, it will add to the body of academic literature.

\subsection{Scope of the Study}

This study focuses on the effect of electronic accounting practices on service delivery (SD) in Ng'arisha SACCO, Bungoma. Other SACCOs, either within or outside of Bungoma, are not included in the study's target population.

\section{Literature Review \\ 2.1. Theoretical Review}

Schumpeter's theory of innovation, as well as technical acceptance theory, were the main drivers in this research.

\subsubsection{Schumpeter's Theory of Innovation}

The theory of innovation was instituted and progressed by Joseph Schumpeter (1838-1950). This theory anchors the independent variable of electronic accounting systems. The initial strategy emphasizes the impact of creativity on business, the environment, and social progress. According to Schumpeter, the economy is based on the allocation of goods provided through various means as seen through static lenses. Economic growth, according to Schumpeter, is a phase of qualitative change fueled by creativity that occurs over time. New goods, new manufacturing techniques, new supply sources, new opportunities, and new approaches to structure in the industry are all manifestations of creativity, according to Schumpeter. He described creativity as a new way of combining previously available tools and stated that entrepreneurs play a critical part in successful inventions. That is, pioneers had to overcome inertia or aversion to new approaches at all society's 
levels in order to achieve their goals. According to Rafinejad (2017), Schumpeter's philosophy stresses creativity while dismissing an entrepreneur's risk-taking and coordinating skills.

The entrepreneurship theory is crucial to this research since it explains the relationship between innovation and entrepreneurship. Economic and social transition was brought on by innovations, as seen in the principle. On the other hand, entrepreneurs use creativity as an impetus to develop innovative technologies, new manufacturing processes, new sources of procurement, new consumer exploitation, and new company structures. In the context of this study, an electronic accounting system provides SACCOs with the ability to experiment with new business models, which are likely to result in economic as well as social improvements among the consumer base. This is seen in how SACCOs utilize services to communicate with their clients and vendors in order to run their businesses.

\subsubsection{Technology Acceptance Model (TAM)}

Fred David developed the Technology Acceptance Model (TAM) in 1989. The theory of reasoned action is the foundation of the model. The TAM is widely regarded as the most influential and widely used theory (Lee, 2015). Initially, the model had four variables: perceived utility, perceived ease of use, attitude toward its use, and actual system uses. Later on, external variables and behavioral purpose were applied to the model (Erasmus, McGoldrick, \& McAdam, 2015). External variables can also influence perceived utility and ease of use, according to the theory (Alharbi \& Drew, 2014). Perceived utility is a major factor in technological acceptance. SACCOs should expect reduced management costs, greater internal performance, and better relationships with business partners, as well as improved competition, improved information quality, access to SACCO accounts, fund transfers, and bill payment (Riyadh, Ghosh, \& Antony, 2014). The model proposes that the user's attitude toward the system's ease of use is the most important element in determining whether the system is used or rejected. If the user feels that the system is easy to use, then this will help him or her to work more efficiently and be more productive. Both perceived utility and attitude toward usage of the system are influenced by the perceived ease of use. According to the TAM, users' attitudes toward electronic accounting systems are affected by perceived utility as well as perceived ease of use. Because of their usefulness and ease of use, people cultivate a favorable outlook toward services (Fethena, 2015). The utility of electronic accounting systems were found to have an effect on the development of SACCOs in this research. Venkatesh and Davis (2014) suggested an extension variable to the original TAM, in which they found other aspects known as external variables that could affect a person's view of a system, such as system features, user preparation and interest in the design process, as well as the implementation process (Chullur, 2014). The TAM was created to clarify as well as forecast specific IT use. Many scholars have used the model to analyze the implementation and proliferation of different information system technologies (Riyadh et al., 2014).

The theory is significant in this study because it suggests that perceived utility as well as perceived ease of use can forecast attitudes toward utilizing electronic accounting systems, and that perceived usefulness influences users' behavioral intention to use electronic accounting systems. Intention to use often ascertains the actual use of electronic accounting systems.

\subsection{Empirical Review}

The present research seeks to contribute to the existing literature by hypothesizing that electronic accounting systems have an effect on service delivery in SACCOs.

\subsubsection{Electronic Funds Transfer Practices and Service Delivery}

In Pakistan, Saleem and Rashid (2014) investigated the connection between customer satisfaction and mobile banking. They collected data using Likert scale questionnaires. The study employed a representative sample of Citibank, N.A., and Standard Chartered Bank. Customers' questions regarding technology's reliability, authenticity, and security were found to be important, according to the study. They also discovered that mobile banking adoption necessitates technical advancement that is both productive and inexpensive, as well as stable and safe. To encourage consumers to embrace technology, it must be effective, quick, and simple to comprehend and use. They also discovered that the advent of low-denomination prepaid cards and lowercost cell handsets had resulted in a widespread proliferation of mobile phones across the globe. Because IT implementation, creative services, protection, consumer confidence, and risk are key indicators of technology adaptation, these results suggested that businesses should focus on them. However, the examination failed to address electronic accounting practices, instead focusing on the adoption of mobile banking.

The World Bank (2016) conducted an examination on cashflow management and financial performance of Nigerian and Gambian SACCOs. The research utilized a descriptive survey method with a sample size of 231 SACCOs. Structured questionnaires as well as interviews were utilized to collect the data. The study discovered that the inability of SACCOs to access funds is still a major problem in Nigeria and Gambia, limiting the formation of new companies and preventing others from expanding and developing. It was discovered that cashflow management is a major constraint in the activities of micro and small enterprises' operations. Debt collection, low sales, and a lack of working capital are three of the top five issues that micro 
and small businesses face, according to the study. However, their study failed to focus on technology as the center of mobile financial efficiency in SACCOs, which is the key focus in the current study.

Pagani (2014) conducted a study on mobile payment services and financial performance among SACCOs in east Africa, Rwanda, Kenya and Uganda. He employed a correlation research design, with a sample of 876 respondents sampled through non-probability approaches. The data was gathered from the respondents through a questionnaire. The study discovered that one of the chief advantages of mobile payment systems among SACCOs in those regions is accessibility (the ability to reach necessary services). The study also discovered that small and micro-businesses benefit the most from using M-Pesa mobile payment, and that the mobile money transfer (MMT) services' major purpose is to minimize the cost of transferring money from one person to another, mainly over long distances. MMT, on the other hand, has not been clearly established in the literature, as it may be alleged to encompass all of the practices (long-distance remittance, micropayments, and informal airtime battering schemes) that use mobile technology to bring financial resources to the unbanked.

Mbogo (2017) investigated the impact of mobile payment on micro-business success and development in Nairobi, Kenya. The research was based on a survey that was carried out by the distribution of questionnaires to obtain data from 409 respondents, all of whom were micro-business owners. The TAM was used in the study, and it was expanded to include other variables that could help predict micro-business success and development. The study discovered that ease, usability, cost, funding, and protection factors are related to micro-businesses' behavioral intentions to use mobile payment services to improve their performance and increase their growth. It was also discovered that mobile money encourages entrepreneurship by offering a forum for the introduction of innovative services as well as improving the performance of small business. However, the examination did not use SD as the dependent variable. In addition, the study only focused on one aspect of electronic accounting practice and ignored e-reporting and e-funds transfer.

\section{Research Methodology}

A descriptive sample analysis was used in this study, and 121 respondents were selected from the mainstream county government and Ng'arisha SACCO. The entire targeted population of 121 respondents was used since they are limited in number, thus making this a census study, as per Mugenda and Mugenda (2015). Questionnaires were used to collect data and they included both closed-ended and open-ended questions constructed on a five-point Likert scale. The questionnaire was pilot tested on $10 \%$ of the sample population to enable evaluation of the reliability and validity of the questionnaire. The collected data was filtered, organized and corded before analysis. Statistical Package for Social Sciences (SPSS) version 26 software was used for the data analysis, which was done in the form of descriptive and inferential statistics. Descriptive statistics includes the means, standard deviations, frequencies and percentages, while inferential statistics includes the coefficient of determination and analysis of variance. The findings are presented in statistical tables accompanied by relevant discussions.

\section{Data Analysis and Discussions}

4.1. Descriptive Statistics for the Study

\subsubsection{The Effect of E-Funds Transfer Practices on SD in Ng'arisha SACCO, Bungoma, Kenya}

The first objective of this study is to determine how e-funds transfer practices affect SD in Ng'arisha SACCO in Bungoma, Kenya. The respondents were asked how much they agree or disagree with the assertions using a five-point Likert scale, where $1=$ strongly disagree, $2=$ disagree, $3=$ not sure, $4=$ agree, and $5=$ strongly agree. The findings are presented in Table 1.

The respondents were asked to comment on whether they thought electronic cash transfers have enabled them to control queuing in their banking halls. As seen in Table 1, the following was discovered: $0.00 \%(0)$ strongly disagreed, $0.00 \%$ (0) disagreed, 2.5\% (3) were undecided, 27.3\% (33) agreed, and 70.2\% (85) strongly agreed. Thus, the majority of the respondents concurred that electronic cash transfer has enabled them to control queuing in their banking halls.

The study also sought to investigate whether electronic money transfer helps customers to save money from their business proceedings on daily basis. The results show that $0.0 \%(0)$ strongly disagreed, $0.0 \%(0)$ strongly disagreed, $0.8 \%$ (1) was undecided, $20.7 \%$ (25) agreed, and $78.5 \%$ (95) strongly agreed. The majority of respondents believed that electronic money transfer helps clients to save money on a daily basis, as seen by the high number $(99.2 \%)$ who agreed/strongly agreed (120). The third item on this subject was to determine whether electronic cash transfer had reduced the theft of money due to having a large amount of cash in the drawers. As seen in Table 1, 0.0\% (0) strongly disagreed, 0.0\% (0) disagreed, $0.8 \%$ (1) was undecided, $19.0 \%$ (23) agreed, and $80.2 \%$ (97) strongly agreed. The majority of respondents (99.2\%) believed that electronic cash transfer has stopped the theft of money that occurs when a large amount of money is stored in drawers. The fourth item aimed to determine whether access to electronic cash transfer has enabled a quick response to customers' needs. Table 1 shows that $0.0 \%(0)$ strongly disagreed, $0.0 \%(0)$ disagreed, $2.5 \%(3)$ were indecisive, $15.7 \%$ (19) agreed, and $81.8 \%$ (99) strongly agreed. In general, it was clear that $97.5 \%$ (118) of respondents agreed that access to electronic cash transfer has allowed them to respond quickly to customer needs. 
Table 1. E-funds transfer practices.

\begin{tabular}{|c|c|c|c|c|c|c|c|c|}
\hline S/No. & E-funds transfer practice & 5 & 4 & 3 & 2 & 1 & Mean & Std. dev. \\
\hline 1 & $\begin{array}{l}\text { Electronic funds transfer has } \\
\text { enabled us to control queuing in } \\
\text { our banking halls }\end{array}$ & $70.2 \%$ & $27.3 \%$ & $2.5 \%$ & $0.0 \%$ & $0.0 \%$ & 4.68 & 0.481 \\
\hline 2 & $\begin{array}{l}\text { Electronic funds transfer helps } \\
\text { customers to save money from their } \\
\text { business proceedings on daily basis }\end{array}$ & $78.5 \%$ & $20.7 \%$ & $0.8 \%$ & $0.0 \%$ & $0.0 \%$ & 4.78 & 0.438 \\
\hline 3 & $\begin{array}{l}\text { The theft of money that occurs as a } \\
\text { result of holding large sums of } \\
\text { money in the drawers has been } \\
\text { avoided thanks to electronic cash } \\
\text { transfer }\end{array}$ & $80.2 \%$ & $19.0 \%$ & $0.8 \%$ & $0.0 \%$ & $0.0 \%$ & 4.79 & 0.427 \\
\hline 4 & $\begin{array}{l}\text { Access to electronic funds transfer } \\
\text { has enabled us to quickly respond } \\
\text { to customers' needs }\end{array}$ & $81.8 \%$ & $15.7 \%$ & $2.5 \%$ & $0.0 \%$ & $0.0 \%$ & 4.79 & 0.464 \\
\hline 5 & $\begin{array}{l}\text { Electronic funds transfer has } \\
\text { helped reduce travel costs for most } \\
\text { of our customers }\end{array}$ & $19.8 \%$ & $57.0 \%$ & $19.0 \%$ & $4.1 \%$ & $0.0 \%$ & 3.93 & 0.743 \\
\hline 6 & $\begin{array}{l}\text { Electronic funds transfer has } \\
\text { reduced the insecurity of cash }\end{array}$ & $47.1 \%$ & $43.0 \%$ & $8.3 \%$ & $1.7 \%$ & $0.0 \%$ & 4.36 & 0.705 \\
\hline 7 & $\begin{array}{l}\text { Electronic funds transfer has } \\
\text { enhanced service delivery in our } \\
\text { SACCO }\end{array}$ & $64.5 \%$ & $35.5 \%$ & $0.0 \%$ & $0.0 \%$ & $0.0 \%$ & 4.64 & 0.481 \\
\hline \multicolumn{7}{|c|}{ Average } & 4.567 & 0.534 \\
\hline
\end{tabular}

Another aim was to determine whether electronic cash transfer has helped reduce travel costs for their customers. The employees' responses (as seen in Table 1) are as follows: $0.0 \%(0)$ strongly disagreed, $4.1 \%(5)$ disagreed, 19.0\% (23) were undecided, $57.0 \%$ (69) agreed, and 19.8\% (24) strongly agreed. As a result, all of the respondents (121) decided that electronic cash transfer has helped to reduce travel costs for most of their customers.

In determining whether electronic funds transfer has reduced cash money insecurity, it was discovered that $0.0 \%(0)$ strongly disagreed, $1.7 \%$ (2) disagreed, 8.3\% (10) were indecisive, $43.0 \%(52)$ agreed, and $47.0 \%$ (57) strongly agreed, as shown in Table 1 . The majority of respondents believed that electronic funds transfer has reduced the insecurity associated with cash money transactions, as evidenced by the high number of respondents who agreed/strongly agreed $(87.0 \%$, or 109$)$.

The seventh element on list was to determine if electronic funds transfers had improved SD in the SACCO. According to the results in Table 1, $0.0 \%(0)$ strongly disagreed, $0.0 \%(0)$ disagreed, and $0.0 \%(0)$ were undecided, $35.5 \%$ (43) agreed, and $64.5 \%$ (78) strongly agreed. The majority of respondents believed, as shown by the high percentage of $100.0 \%$ (121), that electronic funds transfer has enhanced SD in the SACCO. An average mean of 4.567 and a standard deviation of 0.534 indicate that the respondents are affirmative.

\subsubsection{Service Delivery in Ng'arisha SACCO, Bungoma, Kenya}

The study's dependent variable is SD in Ng'arisha SACCO. The respondents were again asked to indicate how much they agree or disagree with statements on the same five-point Likert scale. The findings for this objective are shown in Table 2 and discussed hereunder.

The study sought to investigate whether the respondents believe that electronic accounting practices have improved the speed of SD in their SACCO. As seen in Table 2, 0.0\% (0) strongly disagreed, 1.7\% (2) disagreed, $2.5 \%$ (3) were undecided, $19.8 \%$ (24) agreed, and $76.0 \%$ (92) strongly agreed. The high percentage of $95.8 \%$ (116) demonstrates that most respondents agreed that electronic accounting practices have improved the speed of SD in their SACCO.

The second aim under this theme was to find out whether electronic accounting practices have improved accountability in their SACCO. As seen in Table 2, it was determined that $0.0 \%(0)$ strongly disagreed, $0.8 \%$ (1) disagreed, 1.7\% (2) were undecided, 5.8\% (7) agreed, and 91.7\% (111) strongly agreed. As displayed, 97.5\% (118) of respondents agree that electronic accounting practices have improved accountability in their SACCO.

The third item under this theme was to determine whether electronic accounting practices have improved SD accuracy and excellence in their SACCO. As seen in Table 2, 0.0\% (0) strongly disagreed, $0.0 \%(0)$ disagreed, $1.7 \%(2)$ were undecided, 3.3\% (4) agreed, and 95.0\% (115) strongly agreed. In general, it is apparent that $98.3 \%$ (119) of respondents agreed that electronic accounting practices have improved accuracy and excellence in SD in their SACCO.

The study also sought to establish whether electronic accounting practices have improved the number of loans disbursed in their SACCO. As displayed in Table 2, the employees' responses are as follows: $0.0 \%(0)$ 
strongly disagreed, $0.0 \%(0)$ disagreed, $0.0 \%$ (0) were undecided, 12.4\% (15) agreed, and 87.6\% (106) strongly agreed. Thus, all respondents $100.0 \%$ (121) generally agreed that electronic accounting practices have improved the number of loans disbursed by their SACCO.

\begin{tabular}{|c|c|c|c|c|c|c|c|c|}
\hline S/No. & Statement & 5 & 4 & 3 & 2 & 1 & Mean & Std. dev. \\
\hline 1. & $\begin{array}{l}\text { Electronic accounting practices have } \\
\text { improved the speed of SD in our } \\
\text { SACCO }\end{array}$ & $76.0 \%$ & $19.8 \%$ & $2.5 \%$ & $0.8 \%$ & $0.0 \%$ & 4.70 & 0.601 \\
\hline 2. & $\begin{array}{l}\text { Electronic accounting practices have } \\
\text { improved accountability in our } \\
\text { SACCO }\end{array}$ & $91.7 \%$ & $5.8 \%$ & $1.7 \%$ & $0.0 \%$ & $0.0 \%$ & 4.88 & 0.432 \\
\hline 3. & $\begin{array}{l}\text { Electronic accounting practices have } \\
\text { improved accuracy and excellence in } \\
\text { SD in our SACCO }\end{array}$ & $95.0 \%$ & $3.3 \%$ & $0.0 \%$ & $0.0 \%$ & $0.0 \%$ & 4.93 & 0.309 \\
\hline 4. & $\begin{array}{l}\text { Electronic accounting practices have } \\
\text { improved the number of loans } \\
\text { disbursed by our SACCO }\end{array}$ & $87.6 \%$ & $12.4 \%$ & $0.0 \%$ & $0.0 \%$ & $0.0 \%$ & 4.88 & 0.331 \\
\hline 5. & $\begin{array}{l}\text { Electronic accounting practices have } \\
\text { increased the number of clients } \\
\text { served in our SACCO }\end{array}$ & $94.2 \%$ & $5.0 \%$ & $0.8 \%$ & $0.0 \%$ & $0.0 \%$ & 4.93 & 0.281 \\
\hline 6. & $\begin{array}{l}\text { Electronic accounting practices have } \\
\text { increased customers' trust in our } \\
\text { SACCO }\end{array}$ & $90.1 \%$ & $9.9 \%$ & $0.0 \%$ & $0.0 \%$ & $0.0 \%$ & 4.90 & 0.300 \\
\hline 7. & $\begin{array}{l}\text { Electronic accounting practices have } \\
\text { improved SD in our SACCO }\end{array}$ & $89.3 \%$ & $9.1 \%$ & $1.7 \%$ & $0.0 \%$ & $0.0 \%$ & 4.88 & 0.378 \\
\hline \multicolumn{7}{|c|}{ Average } & 4.87 & 0.376 \\
\hline
\end{tabular}

The respondents were requested to state whether electronic accounting practices have increased the number of clients served in their SACCO. Table 2 shows that $0.8 \%$ (1) was undecided, $5.0 \%$ (6) agreed, and $94.2 \%$ (114) strongly agreed. Subsequently, the majority $99.2 \%$ (120) of the respondents generally agreed that electronic accounting practices have increased the number of clients served in their SACCO.

It was also asked whether electronic accounting practices have increased customers' trust in the SACCO. As seen in Table 2, 0.0\% (0) strongly disagreed, $0.0 \%$ (0) disagreed, $0.0 \%$ (0) were undecided, 9.9\% (12) agreed, and $90.1 \%$ (109) strongly agreed. As exhibited by the high percentage of $100.0 \%$ (121), the majority of respondents agreed that electronic accounting practices have increased customers' trust in their SACCO.

The last item under this theme was to find out whether electronic accounting practices have improved SD in their SACCO. As seen in Table 2, $0.0 \%$ (0) strongly disagreed, $0.0 \%$ (0) disagreed, 1.7\% (2) were undecided, 9.1\% (11) agreed, and 89.3\% (108) strongly agreed. As exhibited by the high percentage of 98.4\% (119), most respondents agreed that electronic accounting practices have improved SD in their SACCO. An average mean of 4.87 and a standard deviation of 0.376 indicate that the respondents are highly affirmative.

Several previous studies support the above findings. For instance, Saito (2003) established that SD had not expressively upgraded in Uganda because of decentralization. When decentralization is set up without important enhancements in administration, conveyance as an inquiry consistently remains (Oyugi, 2000). Nonetheless, Obwana (2000) inferred that monetary and institutional requirements had unfavorably influenced the capacity of the declined county government to sufficiently convey worthwhile administrations to the residents. The study used questionnaires, interviews and focus group discussions, unlike the current study, which only uses questionnaires.

\subsection{Inferential Analysis}

This section presents the inferential analyses, findings and discussions, as well as the hypothesis testing. The findings are presented below.

\subsubsection{E-funds Transfer and Service Delivery}

The means of e-funds transfer and service delivery in SACCOs were regressed. The aim of this study was to determine the causal relationship between e-funds transfers and SD in SACCOs. This helped to test the study's first hypothesis, that e-funds transfer has no statistically significant effect on SD in Ng'arisha SACCO. At a $95.0 \%$ confidence rating, the significance of the R-squared and regression coefficient was checked. Table 3 shows the results. 
Table 3. Regression results for e-funds transfer and service delivery.

\begin{tabular}{|c|c|c|c|c|c|c|c|c|c|}
\hline \multicolumn{10}{|c|}{ Model summary } \\
\hline \multirow[b]{2}{*}{ Model } & \multirow[b]{2}{*}{$\mathbf{R}$} & \multirow[b]{2}{*}{ R-squared } & \multirow[b]{2}{*}{$\begin{array}{c}\text { Adjusted R- } \\
\text { squared }\end{array}$} & \multirow[b]{2}{*}{$\begin{array}{l}\text { Std. error of } \\
\text { the estimate }\end{array}$} & \multicolumn{5}{|c|}{ Change statistics } \\
\hline & & & & & $\begin{array}{c}\text { R-squared } \\
\text { change }\end{array}$ & F change & df1 & dfe & $\begin{array}{l}\text { Sig. F } \\
\text { change }\end{array}$ \\
\hline 1 & $0.897^{\mathrm{a}}$ & 0.805 & 0.804 & 0.292 & 0.805 & 491.810 & 1 & 119 & 0.000 \\
\hline
\end{tabular}

\begin{tabular}{c|c|c|c|c|c|c}
\hline ANOVA $^{\mathbf{a}}$ \\
\hline \multicolumn{2}{c|}{ Model } & Sum of squares & Df & Mean square & F & Sig. \\
\hline \multirow{4}{*}{1} & Regression & 41.936 & 1 & 41.936 & 491.810 & $0.000^{\mathrm{b}}$ \\
\cline { 2 - 7 } & Residual & 10.147 & 119 & 0.085 & & \\
\cline { 2 - 7 } & Total & 52.083 & 120 & & & \\
\hline
\end{tabular}

a. Dependent variable: $\mathrm{SD}$

b. Predictors: (Constant), X1.

An F-significance value of $p=0.000$ in Table 3 shows that the regression model had a $0.00 \%$ chance of rejecting the null hypothesis that e-funds transfer has no significant effect on SD in SACCOs. As a result, the model was significant, and the null hypothesis was rejected because e-funds transfer was found to have a significant and strong positive linear correlation with SD.

Table 4. Coefficient of determination.

\section{Coefficients $^{\mathrm{a}}$}

\begin{tabular}{|c|c|c|c|c|c|c|c|c|c|c|c|}
\hline \multirow{2}{*}{\multicolumn{2}{|c|}{ Model }} & \multicolumn{2}{|c|}{$\begin{array}{c}\text { Unstandardized } \\
\text { coefficients }\end{array}$} & \multirow{2}{*}{\begin{tabular}{|c|}
$\begin{array}{c}\text { Standardized } \\
\text { coefficients }\end{array}$ \\
Beta \\
\end{tabular}} & \multirow[b]{2}{*}{$\mathbf{T}$} & \multirow[b]{2}{*}{ Sig. } & \multicolumn{2}{|c|}{$\begin{array}{c}\text { 95.0\% Confidence } \\
\text { interval for B }\end{array}$} & \multicolumn{3}{|c|}{ Correlations } \\
\hline & & B & $\begin{array}{l}\text { Std. } \\
\text { error }\end{array}$ & & & & $\begin{array}{l}\text { Lower } \\
\text { bound }\end{array}$ & $\begin{array}{l}\text { Upper } \\
\text { bound }\end{array}$ & $\begin{array}{l}\text { Zero- } \\
\text { order }\end{array}$ & Partial & Part \\
\hline \multirow[t]{2}{*}{1} & Constant & 1.228 & 0.152 & & 8.105 & 0.000 & 0.928 & 1.528 & & & \\
\hline & X1 & 0.743 & 0.033 & 0.897 & 22.177 & 0.000 & 0.676 & 0.809 & 0.897 & 0.897 & 0.897 \\
\hline
\end{tabular}

There is proof of a linear relationship between electronic funds transfer and SACCOs' SD; the correlation coefficient $(\mathrm{R})$ of 0.897 in Table 3 suggests a strong positive linear relationship. This means that e-funds transfer has a significant and strong effect on service delivery in SACCOs.

E-funds transfer explains $80.5 \%$ of the variation in SD in SACCOs, according to the coefficient of determination (R-squared) of 0.805 . The model is statistically significant in predicting the effect of e-funds transfer on SD in SACCOs since the significance value is 0.000 , which is below 0.05. In Table 4, e-funds transfer has an unstandardized regression coefficient $(\beta)$ of 0.743 , a correlation coefficient $(\beta)$ of 0.897 , a t-test of 22.177 , and a significance level of $\mathrm{p}=0.000$, confirming the presence of a significant and strong positive linear correlation between e-funds transfer and SD in Ng'arisha SACCO. E-funds transfer is significant in predicting the degree of SD in SACCOs at a $5 \%$ level of significance and a $95 \%$ level of confidence. The regression equation used to approximate the relationship between e-funds transfer and SD is:

$\mathrm{SD}=1.228+0.743 \mathrm{X}_{1}$

From the regression equation, when e-funds transfer changes by 0.743 , the service delivery changes by 1.228. This reveals a positive relation between the two variables.

\section{Summary of Findings, Conclusions and Recommendations 5.1. Summary of Findings}

The important findings of the study are summarized in this section. The objective of this research was to broaden the base of knowledge and test the impact of e-accounting techniques on service delivery.

\subsubsection{The Effect of E-Funds Transfer Practices on Service Delivery in Ng'arisha SACCO, Bungoma, Kenya}

The main objective of this study was to examine the effect of e-funds transfer practices on service delivery in Ng'arisha SACCO, Bungoma, Kenya. The respondents were required to record their observations on whether electronic cash transfer has enabled them to control queuing in their banking halls, and $70.2 \%(85)$ of the respondents generally agreed that electronic cash transfer has enabled them to control queues in their banking halls. The study also sought to investigate whether electronic money transfer helps customers to save money from their business proceedings on a daily basis. As exhibited by the high percentage (99.2\%), most of the respondents (120) agreed that electronic money transfer enables consumers to save money from their business proceedings on a regular basis. Item number three aimed to find out whether electronic cash transfer has eliminated money theft as a result of holding large sums of money in drawers. As exhibited by the high percentage of $99.2 \%$, most respondents (120) agreed that electronic cash transfer has prevented the theft of 
money that arises from keeping a lot of cash in the drawers. Item number four under this theme was to find out whether access to electronic cash transfer has enabled a quick response to customers' needs. In general, $97.5 \%$ (118) of respondents concurred that access to electronic cash transfer has enabled them to respond quickly to their customers' needs. The study pursued to ascertain whether electronic cash transfer has helped reduce travel costs for most of their customers. All respondents 100\% (121) generally agreed that electronic cash transfer has helped to reduce travel costs for most of their customers. In establishing whether electronic funds transfer has reduced insecurity due to cash money, it was discovered that the majority of respondents believed that electronic funds transfer had decreased insecurity associated with cash money transactions, as indicated by the high percentage of $87.0 \%$ (109). Finally, item number seven was to ascertain whether electronic funds transfer has enhanced the SACCO's SD. As indicated by the high percentage of 100.0\% (121), all respondents concurred that electronic funds transfer has enhanced service delivery in the SACCO.

5.2. Conclusion

The conclusion for each study objective was obtained from the findings and explanations of the results in the section below.

\subsubsection{The Influence of E-Funds Transfer on Service Delivery in SACCOs}

The specific objective here was to establish the impact of e-funds transfer on the delivery of service in SACCOs. The correlation value $(\mathrm{R})$ of 0.897 reveals a strong positive linear link between e-funds transfer and SACCO SD. As a result, e-funds transfer has a significant and strong relationship with SD in SACCOs.

Ho1: E-funds transfer has no significant effect on SD in SACCOs was the first null hypothesis. As a result, because e-funds transfer exhibited a substantial and relatively strong positive linear connection with SACCO $\mathrm{SD}$, the null hypothesis was rejected and the model was significant. The study concluded that e-funds transfer influences SD in Ng'arisha SACCO.

\subsection{Recommendations}

The study recommends that SACCOs should embrace the electronic transfer of funds for their operations to enable queue control and help customers to save money from their business proceedings on a daily basis. In addition, the theft of money that arises from keeping a large amount of cash in the drawers has helped to reduce travel costs as well as reduce insecurity due to cash money and enhance SD in the SACCO.

SACCOs should automate their payments to improve transparency and accountability as well as ensure effectiveness in terms of the timeliness of the service and all customers to make direct payments for services through mobile banking. Moreover, it will enable the payment of suppliers and creditors through electronic payment platforms, the issuance of loans to creditors using electronic payment platforms, the enhancement of recording and reporting mechanisms in SACCO, and the improvement of cash management. SACCOs should automate their reporting mechanisms to enhance the effectiveness of report generation and invoicing, issue receipts using electronic systems, share and disseminate their reports using electronic systems, conduct auditing services using an electronic system, and improve overall service delivery.

\section{References}

Alharbi, C., \& Drew, K. (2014). Pearls Vs Camel financial monitoring. Basics and beyond-transitional and transformational leadership for co-operatives. Paper presented at the Gaborone International Centre, Gaborone, Botswana.

Boeuyer, R. (2016). User acceptance of computer technology: A comparison of two theoretical models. Management Science, 35(1989), 982-1003.

Chau, P., \& Lai, R. (2015). An attitudinal model of technology-based self-service: Moderating effects of consumers traits and situational factors. Journal of Academy of Marketing Science, 30(3), 184-201.

Chullur, F. D. (2014). A technology acceptance model for empirically testing new end-user information systems: Theory and results. Doctoral Dissertation. Cambridge, MA: MIT Sloan School of Management.

Erasmus, J., McGoldrick, E., \& McAdam, R. (2015). A critical review of e-service in Northern Ireland electricity. Managing Service Quality, 13(6), 463-470. https://doi.org/10.1108/09604520310506522

Fethena, H. (2015). Financial performance of non-banking finance companies in Pakistan. Interdisciplinary Journal of Contemporary Research in Business, 2(12), 732-744.

Henry, W., Adeniran, G., \& Olwale, N. (2014). Effects of accounting information management on profitability of Nigerian banking industry. International Journal of Humanities Social Sciences and Education (IJHSSE), 1(9), 100-105.

Hla, R. W., \& Teru, P. L. (2015). Efficiency of accounting information system and performance measures. International Journal of Multidisciplinary and Current Research, 3, 976-984.

Jenkins, M. (2018). New developments in customer service training. Managing Service Quality, 6(2), 49-56.

Kinuthia, O. N. (2017). Effects of financial innovation on the financial performance of deposit taking SACCOs in Nairobi County. Unpublished Research Project, University of Nairobi.

Lee, A. (2015). E-S-QUAL: A multiple-item scale for assessing electronic service quality. Journal of Service Research, 7(3), 213-234.

Maiyo, J. (2015). The effect of electronic banking on financial performance of commercial banks in Kenya. Unpublished MBA Thesis University of Nairobi. 
Mbogo, T. (2017). Information technology good for saccos: Business and tech. Retrieved from http://www.capitalfm.co.ke/business.

Mugenda, O., \& Mugenda, A. (2015). Research methods. Qualitative and quantitative approaches. Nairobi: Acts Press.

Muhindo, T. M. H., \& Zhou, R. W. (2014). Unifying the fragmented models of information systems implementation. In Boland J. R. and Hirshheim (2014), Critical Issues in Information Systems Research. New York: John Wiley.

Municipal Research and Service. (2015). The adoption of automatic teller machines in Nigeria: An application of the theory of diffusion of innovation. Issues in Informing Science and Information Technology, 6(5), 373 -393.

Murungi, M., \& Kayigamba, G. (2015). An empirical evaluation of US bank customer perceptions of the impact of technology in service delivery in the banking sector. International Journal of Retail \& Distribution Management, $31(4), 190-202$.

Ng'arisha SACCO. (2018). An overview of SACCOs in Kenya in Pursuit of ideas to develop savings and credit cooperatives. Learning from Kenyan SACCOs, News Paper for Cooperative Movement in Kenya, pp. 1-4.

Njuguna, J. (2014). The technological needs of SACCOs with regulator's expectations. Retrieved from www.accosca.org/index.php?...technological-needs-of-sacco.

Obwana. (2000). Fiscal decentralisation and sub-national government finance in relation to infrastructure and service provision in Uganda.

Olubendi, J. (2016). E-service quality: A model of virtual service quality dimensions. Managing Service Quality, 13(3), 233246. https://doi.org/10.1108/09604520310476490

Oyugi, W. O. (2000). Decentralization for good governance and development: Concepts and issues. Regional Development Dialogue, 21(1), 3-25.

Pagani, K. (2014). More firms angle to tap into cashless Matatu payment system, Business News, Standard Media, Kenya, May 4th 2014. Retrieved from: www.standardmedia.co.ke > Business > Business News.

Rafinejad, W. (2017). Customer value in business markets: An agenda for inquiry. Industrial Marketing Management, 30(3), 315-319.

Riyadh, H., Ghosh, S., \& Antony, J. (2014). Determining and assessing the determinants of eService operations. Managing Service Quality, 13(1), 39-53.

Sadona, S. A. (2016). What really drives a fast company? Journal of Management, 65(79), 651-926.

Saito, F. (2003). Decentralization and development partnerships. Annual Review of Political Science, 6.

Saleem, B., \& Rashid, T. (2014). Competition and innovation in the consumer e-payments market considering the demand, supply, and public policy issues. Federal Reserve Bank of Chicago Public Policy Working Paper No. EPS-2013-4.

SASRA. (2017). SACCO supervision annual report. An Annual Report on the Operations and Performance of DepositTaking SACCO Societies (DT-SACCOs) in Kenya, Nairobi.

SASRA. (2018). A peek into Kenya's SACCO Subsector. Retrieved from http://www.sasra.go.ke/newsupdates/latestnews/50-a-peek-into-kenya-s-sacco-subsector\#.U6AubaMUfiA.

Sharma, J. N. (2016). Challenges in implementing electronic banking strategy by commercial banks in Kenya. Unpublished MBA Thesis University of Nairobi

Stefanou, C. (2006). The complexity and the research area of AIS. Journal of Enterprise Information Management, 19(1), 9-12. https://doi.org/10.1108/17410390610636841

Tazik, S., \& Mohamed, G. (2014). Information systems planning in a turbulent environment. European Journal of Information Systems, 9(2000), 3-15.

Temple, L. (2015). Competitive Intelligence: How to gather, analyze and use information to move your business to the top. New York: Touchstone.

Venkatesh, S., \& Davis, K. (2014). Developing a world-class CI program in telecoms. In Prescott, Proven Strategies in Competitive Intelligence: Lessons from the Trenches (pp. 148-167). New York: Wiley.

Whitaker, U. (2014). A new paradigm in payments: The strengths of networks. Journal of Payments Strategy \& Systems, 4(3), 277-288.

World Bank. (2016). The contribution of market intelligence to tactical and strategic business decisions. Marketing Intelligence ङ Planning, 18(1), 6-8. 